\title{
Authorship in the interstices of history, biography, reality and memory: Histoire(s) du Cinema and Cabra Marcado para Morrer
}




\section{Resumo}

Este artigo contrasta Histoire(s) du cinéma de Jean-Luc Godard e Cabra Marcado Para Morrer de Eduardo Coutinho, estão engajadas com a questão da autoria no cinema. Enquanto a imagem de Godard enfatiza a capacidade que tem um filme de transmitir a visão de mundo pessoal de um artista, a presença de Coutinho na tela funciona menos como um meio de subjetivar a obra do que como um catalizador instigando cetas reações nos "atores" filmados.

\section{Palavras-chave}

cinema, autoria, Godard, Eduardo Coutinho

\section{Abstract}

This essay contrasts Jean-Luc Godard's Histoire(s) du cinéma and Eduardo Coutinho's Cabra Marcado Para Morrer, examining how these works engage with the issue of film authorship. While Godard's image stresses film's ability to convey an individual artist's worldview, Coutinho's on-screen presence functions less as a means to subjectivize the work than as a catalyst instigating certain reactions in the filmed "actors".

\section{Key words}

cinema, authorship, Godard, Eduardo Coutinho 
$\mathrm{T}$

The examination of Jean-Luc Godard's Histoire(s) du cinéma (1989-1998) and Eduardo Coutinho's Cabra marcado para morrer (1984) engages the intricate issue of film authorship within the domains of the essay and the documentary films. While Godard's image stresses the medium's ability to convey an individual artist's subjectivity, Coutinho's on-screen presence, rather selfeffacing, functions less as a means to subjectivize the work than as a catalyst instigating certain reactions in the filmed "actors." The comparison between the two works reveals the intricate ways in which film makes manifest a personifiable author not through unique, untouched and genuine displays of interiority and worldviews, but by means of the articulation of images that escape the domains of the directors' subjectivity - images either produced by others or revealing of the experiences of others.

Godard forges the history of cinema in four two-part episodes relying exclusively on a montage juxtaposing scenes from films, cartoons, photographs, and paintings, to excerpts from books quoted in voice-over, film dialogues and music. His enterprise constitutes a type of authorial self-inscription that relies on citation, on the works of others. The fabric for Coutinho's Cabra, in turn, is the experiences of others. His documentary brings back to life a film suspended by the 1964 coup d'etat in Brazil. The aborted film, initially conceived as fiction, dramatized a real event; namely, the assassination of militant peasant João Pedro Teixeira by the police and landowners. Shot during the transition to redemocratization in the 1980's, Cabra rescues the first film by documenting the director's search for the peasants who partook in the revolutionary movement, especially Elisabeth, João Pedro's widow. The result is a documentary contemplating, in equal 
amounts, its own making, the country's political trajectory, and the effects of the coup d'état in the lives of a group of peasants individuals who, 20 years before, had in fact been hired by Coutinho to act out the story of the assassinated leader.

The case study of Histoire(s) and Cabra reveals how the two directors choose friction, or conflict, as their main modus operandi. Godard's history of the medium elects Eisensteinian montage to explore relations between historical facts, rather than the facts themselves. Coutinho's history of the nation privileges the encounter between camera and subject filmed; what matters to him is not so much the content of the subjects' speeches, but how the presence of director and apparatus shape these subjects' discourses. To wit, the two filmmakers blend in autobiographical accounts to their films, brining to them another kind of friction - that between the collective and the individual, the public and the private spheres.

The analysis of the types of authorial self-representation in works pertaining to different genres - essay film and documentary also allows for a comprehensive investigation of issues of history, memory, self-inscription and self-examination within the framework of films displaying their own directors on screen in the role of auteurs. This study illustrates, in addition, the different ways in which each work dialogues with a national tradition of film authorship, and how these traditions relate to each other.

\section{Indexicality for the author-in-the-text}

The discussion of authorship that ensues from the comparison between Histoire( $s$ ) and Cabra engages with the negotiation between the medium's potential for documentation and the author's selfexpression (the tension between film's ontological and discursive qualities), the implications of intertextual practices, and the balance between collective and individual. Central to the examination of authorial self-inscription in the two works is the impact of the physical presence of Godard and Coutinho, both onscreen and through voiceover commentary, on the question of authorship in cinema; in other words, the implications of the director's corporality for those 
conceptions of film authorship in which disincarnated "entities," "agencies," and "functions" stand in for the artist's name, cautious as such conceptions are in assigning authorship to a single person in a medium notable both for its collaborative modes of production and for its heterogeneity.

The Platonic opposition between showing (mimesis) and telling (diegesis), thoroughly explored within the domains of film narratology and semiotics, contrasts a model in which the narrator "hides". behind the events shown, letting them speak for themselves, to one that renders explicit the marks of enunciation. Commenting on Plato's distinction between mimesis and diegesis in Narrative Discourse, Gérard Genette notes that in the mimetic mode we find "direct speech in the manner of drama," whereas in the diegetic mode we find a "poet," or an expressing voice, who "himself is the speaker and does not even attempt to suggest to us that anyone but himself is speaking" (162). In a hypothetical scenario where mimesis and diegesis could be easily set apart, the former would efface any marks of enunciation, condemning to seclusion the thereby untraceable narrator.

In cinema, the distinction between showing and telling is nearly unsolvable, for films combine devices associated with both modes, as Tom Gunning and André Gaudreault have argued. Taking further the project to define film's narrating stages carried out by authors such as Etienne Souriau, Gunning establishes a model for filmic discourse that interrelates the staging of elements to the camera in the pro-filmic, the framing of the image and the editing (18). Nonetheless, Gunning calls attention to the evidence of narrative intentions behind choices related to acting style, lighting, set designs, and so on (19). Gaudreault, meanwhile, recognizes that films show and tell at the same time (101). The heterogeneity of film narrative hence raises a number of questions, ranging from the validity of divorcing showing from telling to the possibility of locating a narrator and the question of whether or not narrator and author may ever coincide; a possibility that is likely to appall literary theorists, who have long argued; often rightly, for the distinction between the two.

Both Histoire(s) and Cabra present their directors on screen in the role of commentators; rather than tell a story, they comment on 
the images they orchestrate, and,-in the case of Coutinho, instigate. The directors' onscreen presence solves two of the aforementioned problems - that of locating the enunciating agency in film and that of relating this agency to the author. Histoire(s) and Cabra merge onscreen and voice-over commentators with the films' auteurs; fleshing out that discursive function both with their voice and identifiable faces, providing it with a name and an indexicality. Regardless of the extent to which the two directors perform to the camera, or the degree of artifice that, in the case of Godard, is used to manipulate the texture, speed and pitch of his vocal utterances, this type of directorial inscription endows these films with a firstperson voice that is as palpable as its source is concrete. Asserted as the expression of identifiable authors - which varies in degree from Histoire(s) to Cabra - these works openly display film's discursive mode. Furthermore, the extended use of the possessive in Histoire(s), where Godard discloses the partiality of his historical account, and the references to Coutinho's own career in Cabra, whose trajectory parallels the country's political life, leave no doubt about the personal dimension of these projects, however variable. The films grant us even the confiding creator dismissed as a myth in Roland Barthes's. "Death of the Author" (209), with Godard confessing his historiographical anxieties and Coutinho sharing his obsession with his aborted project - most importantly, with both directors partially integrating the topic of their own investigations.

Another personal element evoked by Coutinho and Godard is the very nature of their projects. Both Cabra and Histoire(s) occupy a large time span in the careers of their respective directors; in fact, the English version of the Brazilian title (Twenty Years After) stresses the temporal interval between the shooting of the initial project (1964) and the release of its documentary version (1984) - an information that is nonetheless absent in the film's original title. The episodes of Histoire( $s$ ), in turn, range from 1989 to 1998; yet their origins can be traced back to a series of lectures that took place in Montreal, 1978, which generated a book entitled Introduction à une véritable histoire du cinéma, published in 1980. The lectures were initially supposed to be delivered by Henri Langlois, who passed away 
that year and was then replaced by Godard (MacCabe 294). This literary genesis, ${ }^{1}$ which makes Histoire( $s$ ) as long a project as Cabra (even if both present discontinuities), at the same time emphasizes the multimediatic quality of Godard's project, evident in the film's use of paintings, photographs, cartoons, music and literature, and equally in the director's decision to extrapolate the video format, expanding it both to audio CD and book form. Concomitantly, Histoire( $s$ )'s literary origin stresses Godard's multifaceted approach to the history of film - one that perpetuates a French tradition placing the director as theorist, critic and poet, at once researcher and object of research, implicated as Godard is in the very history he "writes" (or edits).

Instead of asserting their directors as the sole producers of the material of their expression, and rather than staging the auteurs as the only expressive agency in their works, Histoire(s) and Cabra constitute an amalgam of the voices of others - other films and other artists which form Histoire(s)'s intertextual basis, including voiceover speeches uttered by actors, directors, intellectuals, and politicians; and, in Cabra, other crew members, two narrators who share with the director the voice-over commentary, and Brazilian peasants, the real actors of the investigated events. While undoubtedly expressive (even if to varying degrees), these directors embody the role of what in literature Mikhail Bakhtin called orchestrator ${ }^{2}$, and in cinema Christian Metz theorized as great image-maker, or master of ceremonies $(21)^{3}$ : Far from annihilating authorial expression, the incorporation of other voices in the two examined works empowers the directors with the ability to re-signify and intervene in a tradition. Revisiting discussions about film authorship, Gunning states that "the film-maker functions less as a scriptor than a fashioner of palimpsests, texts written over other texts creating new meanings from the superimposition of old ones" (Films of Fritz Lang 6). Both the act of

1. Collin MacCabe suggests that the first draft of Histoire(s) du cinema is a 1966 speech entitles "Thanks to Henri Langlois," published in Le Nouvel observateur on Jan. 12 (202)

2. See Bakhtin, M. M. The Dialogical Imagination: Four Essays. Ed. Michael Holquist. Austin: University of Texas Press, 2001.

3. Metz borrowed this term from Albert Laffay's Logique du cinéma 
quoting in Histoire(s) and the act of recollecting in Cabra entrust Godard and Coutinho with the ability to forge a collective memory via the orchestration of discourses uttered by others, restoring agency to the film author.

\section{The author between the images}

Relying mostly on a montage of pre-existing images shot by various filmmakers, and made neither for the cinema nor for TV, Histoire(s) du cinéma is, in Céline Scemama's terms, an "erratic" work (10). The series lacks both a site of shooting and a'site for projection (10); it is neither easily classifiable as a cinematic work (the closest category is the essay film), nor is it a historical document in the strict sense. Histoire(s) lacks linearity or any concern with causal relations, and openly dismisses documental accuracy. The historian, here, is also a filmmaker, poet, sociologist and philosopher.

Nonetheless, Godard's project ultimately comprises several of the elements expected from the possible historiographical approaches to film. The great-man history is evoked in the focus on inventors (the Lumière brothers), producers (Irvin Thalbergh, Howard Hughes), theorists (André Bazin, Sergei Eisenstein, Serge Daney), and directors (Jean Renoir, Charles Chaplin, Robert Bresson, Roberto Rossellini, Alfred Hitchcock, François Truffaut, Glauber Rocha). Consonant with the great-man view is a hierarchization of artists, with Godard either simply neglecting young names or asking, in voiceover, "For 50 Cecil B. De Mille, how many Dreyers?" Histoire(s) displays also a social-political approach to the history of cinema, with the privileging, for example, of World Wars I and II. A technological history is articulated in musings about the impact of the light cameras invented by Richter and the negative repercussions of television. "If American cinema ruined French cinema after WWI," meditates Godard, "after WWII the TV allowed American cinema to finance - that is, to ruin - all of European cinema" (episode 1A). In sum, the series covers the history of the medium from the multiple standpoints adopted by film historians, from the accounts grounded on "great men," to the aesthetic, social-political, and technological histories. 
Histoire(s) also revisits theoretical issues - the relationship between images and reality are articulated in mottos such as "dream factory," "the successor of photography," and cinema's desire to be "more real than reality." The controversial relations between film and other art forms supplement the series' theoretical repertoire. These relations are epitomized in Histoire( $s$ )'s multimediatic aspect, as well as in references to literature via, firstly, the organization of the episodes in "chapters;" secondly, the use of the recognizably Godardian intertitles, with letters arranged in the mode of concrete poetry; and thirdly, through images of Godard flipping through the pages of books, reciting their titles, reading, and typewriting. A believer in the primacy of the image, Godard is, however; far from dismissive of texts. On the contrary, he explores texts' visual and aural qualities, both in the graphic disposition of phrases and in the exploration of the rhythmic aspects of words and sentences. Finally, the series is also about how Godard relates to both historicizing and theorizing the cinema.

Histoire(s) is divided in four two-part videos. Chapter $1 \mathrm{~A}$ is entitled "Toutes les histoires" (All Histories); 1B, "Une histoire seule" (Only One History); 2A, Seul le cinéma (Cinema Only); 2B; Fatale beauté (Fatal Beauty); 3A, "La monnaie de l'absolu" (The Currency of the Absolute); $3 \mathrm{~B}$, "Une vague nouvelle" (an inversion of Nouvelle Vague); 4A, "Le contrôle de l'univers" (The Control of the Universe); and 4B, "Les signes parmis nous" (The Signs Among Us). The relations between the series' different chapters, with their titles sometimes opening an episode, sometimes appearing in the middle of it, in itself reveals how organizational principles such as demarcations of beginning, middle and end are subverted in Histoire(s)-echoing the director's sarcastic approach to narrative linearity (in a debate with Henri-Georges Clouzot early in his career, Godard famously stated that he agreed that films should have a beginning, a middle, and an end, but not necessarily in that order) ${ }^{4}$.

Histoire(s)'s chapters stand in a dialogical relationship with each other; themes announced in intertitles recur in all episodes.

4. Jean-Pierre Gorin describes the now legendary event in an interview featured in the Criterion DVD of Masculine, Feminine 
"Darkness Answers" flashes in different parts of the series; just as the titles of some chapters reappear in others as intertitles. Repetition acquires rhythm, endowing the episodes with both a poetic and a musical structure. The reappearance of ideas in the videos' different parts creates the equivalent of poetic rhymes connecting all of them - rhymes that are both aural (when these ideas are heard on the soundtrack) and visual (when they appear in the form of either repeated intertitles or recurring film images). These reverberations are also comparable to musical choruses, and Godard imprints the series with his signature by creating a soundtrack that is by no means submitted to the images, even if its juxtaposition to the visual material generates different meanings. Histoire(s)'s soundtrack has a life of its own. Godard's voice-over repetitions of "Histoire with an " $\mathrm{s}$ " in a monotonic yet cadenced mode, along with the rhythmic sound of a typewriter, lingers on in the spectator's memory until after the end of episode 1A. Yet, after one viewing one would have difficulty to point out which images were juxtaposed to this "music." In the end, the very decision to release the series on audio $C D$ is indicative of the soundtrack's relative self-sufficiency.

Likewise, the publication of Histoire(s) on book form suggests the autonomy of images and texts as pictorial and literary objects - the books are composed by stills taken from the videos and texts arranged in the form of verses. The musical structure contaminates the visual track; the flashing of both intertitles and images compose visual choruses, with on the one hand titles appearing in sometimes regular, sometimes irregular, intervals, and on the other, flickering shots adding rhythm to dissolves and superimpositions. Sound and image exist in counterpoint, functioning as independent melodies played simultaneously, both contrasting with each other and affecting each other's meanings - two autonomous objects in constant dialogue, perpetuating the director's signature use of visual and sound tracks.

The organization of pre-existing images and sounds in new relations is at the basis of Histoire(s). In his analysis of Godard's non-linear history of cinema, Junji Hori calls attention to the presence of a dynamics once defined by Gilles Deleuze as "the method of the between." In Hori's words, "Godard wishes to show what lies 
'between' two periods of history. What matters for him is not simply to follow chronologically a historical past, but to perceive an 'echo' between several times by means of a "cinematographic scan of history".' (Hori 338). Godard's interest lies not in the historical events themselves, but in what he calls "the history of history;" his, says Hori, is "an attempt to examine an historical relationship that is not simply reduced to causality" (338).

What ensues from this is an emphasis on unexpected (noncausal) relations, constituting a discourse that, though made of preexisting images, constantly re-invents them, giving these images new meaning and, consequently, new life - Deleuze said that Godard's focus is not on the content of the image, but on form, "its means and functions, its falsifications and creativities" (Time-Image 10). Different temporalities and political conflicts are brought together when Goya paintings are used in a segment dedicated to WWII (1A); or when, in 4B, Godard chains scenes of Ivan the Terrible with newsreels footage of Stalin and the close-up of a bloodstained man in Chechnya (Hori 339). This juxtaposition, in turn, evokes Eisenstein - the "man" becomes the "idea" lying between the images ${ }^{5}$. Back to $1 \mathrm{~A}$, a microphone invades the frame where Godard stands and moves towards his face, calling to mind both the radio era and the microphone in close up from Orson Welles's Magnificent Ambersons (1942). In that film, which ironically escaped the director's control in postproduction, the microphone had marked Welles's authorial input, revealing the director to spectators by tying the voice of the narrator to that of the author. This indirect reference not only brings two temporalities together by evoking the 1940's, but also creates an analogy between Godard and Welles (himself a radio man), brothering them as mavericks.

It follows that Godard's historical methodology privileges montage over chronology - as usual, the director reasons by means of associations rather than causality and linearity. Central to the opposition between the two is the issue of remembrance. Chapter

5. Hori calls attention, however, to the fact that Godard, unlike Eisenstein, exerts no control over the "third image" obtained by the collision of the other two (356). 
$2 \mathrm{~A}$ depicts a long conversation between the director and Daney about the very possibility of telling the history of cinema. Godard claims that this history has been "fairy-taled, but never really told," calling attention to the artificiality of imposing linearity to historical facts. Daney, conversely, argues that French New Wave directors occupied a privileged position in the history of cinema - a thought that betrays a concern with linearity:

The New Wave is the only generation of the 50's and 60's that found itself in the middle of both the century and perhaps of cinema. That was a great privilege. It occurred in the middle of the century, and also in the middle of cinema ... Your good fortune was to start at the right time; you inherited a history already rich and complicated, and you all took a lot of time to see a lot of movies, first as film-lovers, then as critics. You had a personal idea of what was important in that history ... That Griffith came before Rossellini, that Renoir came before Visconti. You had a sense of your emergence in a history still capable of being told ... You had enough knowledge and passion to determine the before and the after. We live before something and we live after something. Having begun in the middle of the century, knowing what you'd inherited, what you'd rejected or accepted.

Godard, nevertheless, states his difficulty in understanding the notion of before and after; his concern about historicizing is also a concern about temporality, ultimately manifested in the director's merging of past and present by means of citational practices. Citation, as Monica Dall'Asta notes in her essay on Histoire (s), is where past and present meet, where "past becomes incorporated into a present praxis;" it is, in addition, the site where "passivity and activity come to coincide" (360), where the spectator of films appropriates preexisting images in order to articulate a different discourse. 
The fusion between different temporalities articulated in Godard's appropriation of past images into a present articulation evokes philosophies of memory. In Le Bergsonisme, Deleuze recapitulates Henri Bergson's concept of mémoire-contraction the idea that two moments fuse into one another in the act of remembering; the belief that memory compresses, or condenses, past and present (46). To be sure, Bergson does believe in an ontological past that is different from the psychological experience of it in the present (Deleuze 51). The indissociability between past and present lies in the fact that the past event has once been a present event - by the same token, the present is bound to become past (Deleuze 54). Deleuze's own conceptualization of the "time-image" defines the collapsing of different temporalities within one cinematic image after WWII, says Deleuze, the cinema started to produce images instilled with duration, which, to Bergson, is defined less by the succession than by the coexistence of different temporalities (Bergsonisme 56) ${ }^{6}$.

By arranging film images from the past in new configurations, Godard condenses past and present by attaching new meanings to specific shots - meanings that spring from a current state of mind, or from a current necessity. When the director matches an image of Giulietta Masina in La Strada with takes of the young boy jumping to death in Rossellini's Germany Year Zero (1A), he adds a new meaning to the Fellini film. Gelsomia's solitude and abandonment, which brothers her to the boy, can be also read as compassion and piety feelings certainly shared by the director ${ }^{7}$. Though undeniably nostalgic for the past invoked by these images, Godard nonetheless refuses to simply reconstruct this past. On the contrary, it is by refashioning past images that he maintains them alive.

A cinematic memory may thus be fabricated, as the dialogue with Daney also suggests. This idea is rescued in the last part of the

6. See also Deleuze, Gilles. Cinema 2: The Time-Image. Minneapolis: University of Minnesota Press, 1989.

7. Jacques Rancière analyzes the same sequence in "Godard, Hitchcock, and the Cinematographic Image." In For Ever Godard. Ed. Michael Temple, James S. Williams and Michael Witt. London: Black Dog Publishing, 2004. 227. 
series - "If I force a souvenir all of a sudden I understand that what comes to me I imagine; I no longer remember" (4B). In short, the historian's account might be just as artificial as any piece of fiction, as suggested in intertitles from the opening of chapter $2 \mathrm{~A}$ : "To give a precise description of what never happened is the work of the historian." Writing on Histoire(s), Eduardo Gruner reminds us of conceptions of history in which "to access the truth is to produce it." Such an approach, Gruner argues, "refutes the empirical scission between subject and object, and the consequent contemplative conception of knowledge, substituting it for a type of knowledge and interpretation that are active" (84). Godard's insistence on stressing the biased, and, most importantly, artificial aspects of his version of the history of cinema entails a form of historiography that favors construction over re-construction. Perpetuating Godard's narrative strategies, Histoire (s) follows a logic that is more associational than causal, dictated by collage rather than linearity. Godard's historical discourse resorts to graphic and sonic montage to the detriment of chronology and continuity, and privileges poetry and analogy over a commitment to factuality. The director proceeds by free interpretation and confusion rather than by accuracy and clarity: Chaplin and Renoir are matched by the juxtaposition of the clown's image with the words "the rules of the game;" likewise, Godard's account suggests that, "if George Stevens hadn't been the first to use the first $16 \mathrm{~mm}$ color film in Auschwitz and Ravensbruck, Liz Taylor's happiness might never have found a Place in the Sun," thus fabricating causal relations between horror and splendor, while also revealing the director's penchant for puns and wordplay. The juxtaposition between Taylor's face and images of concentration camps, according to MacCabe, "analyzes the force of Taylor's smile in terms of Steven's desire to celebrate life after his experience of death" (299) while shooting the horrors of the Holocaust. If Godard somehow redeems Stevens, he also reiterates, via the usual clashes, one of his main theses: cinema's lamentable indifference to the abuses of WWII.

In his discussion about cinema's relations to war Godard condensates the teachings of André Bazin with the strategies of Eisenstein - obsessing about cinema's indexical potentials (the 
importance of registering the real) while operating according to the technique that consecrated cinema's capacity to rearrange the real in new configurations. As Hori puts it, Histoire(s) incessantly alternates between "iconophilia and iconoclasm, the religion of image and the science of montage" (334).

Himself a victim of the war that most obsesses Godard in Histoire(s), Walter Benjamin also underlies the director's methodology. The fusion between past and present in the fabrication of a cinematic memory accommodates Benjamin's theories in "Theses on the Philosophy of History." In the director's free-associative and citational practices, the past does not exist as a fixed, immutable series of events; rather, it gains meaning through the current interpretation of such events, which in turn reflects a present necessity (Theses 225). Explaining Bergson, Deleuze claims that it is a mistake to assume that the past ceases to exist. "We confuse," says Deleuze, "the Being with the present-being" - the past simply ceases to act, but is continues to exist, albeit in abstraction (Bergsonisme 49). As unclosed entity, the past is thus open for new articulations.

Godard's intertextual history of cinema, in turn, evokes the German philosopher's procedures in The Arcades Project - the unfinished history of the Parisian $19^{\text {th }}$ century arcades. ${ }^{8}$ In the words of Howard Eiland and Kevin McLaughling, Benjamin considered the arcades "the most important architectural form of the $19^{\text {th }}$ century ... which he linked with a number of phenomena characteristic of that century's major and minor preoccupations" (Arcades. ix). Defined by Benjamin himself as "the theater of all my struggles and all my ideas" (x), The Arcades Project displays the fragmentary, montage-like, and citational structure found in Histoire(s). Both Benjamin and Godard conform to the conception of the historian as collector of pre-existing material; in their Foreword for the American edition of the Arcades, Eiland and McLaughling define the book as an "ostensible patchwork," "the working of quotations into the framework of montage, so much so that they eventually far outnumber the commentaries" (xi).

8. I am indebted to Ismail Xavier for calling my attention to the usefulness of The Arcades Project for the understanding of Histoire(s) du cinéma 
Arcades and Histoire( $s$ ) use cultural and artistic manifestations (architecture and cinema) to meditate on the political history of a century. Such a dynamic is found, for instance, in Godard's musings on cinema's inefficiency in documenting the horrors of the Second World War. Likewise, Benjamin establishes a parallel between Napoleon's failure to understand "the functional nature of the state as an instrument of domination by the bourgeois class" and the architects' failure to understand "the functional nature of iron, with which the constructive principle begins its domination of architecture" (Benjamin Arcades 4). In both cases, director and philosopher freely associate art and politics.

Furthermore, Arcades and Histoire(s) constitute enterprises of epic proportions. Benjamin never concluded his historical project, abandoning it in the spring of 1940, when he left Paris to escape the advancing German army. Similarly, Godard refuses to conclude Histoire(s) - the open ended structure of each episode avoids closure, while the images from the past are resuscitated in different associations, given new life at each new articulation, thus resisting death. Most significantly, Godard recently edited a shorter version of the series, released as an 84-minute-long film entitled Moments choisis des 'Histoire(s) du cinéma' (2004) - as if the project refused to be given a full stop, remaining open for new articulations.

Benjamin's unfinished, open-ended project evokes his "Theses" through the idea of a lively, mutable past, of a past that refuses to be fixed in time and is re-interpreted according to the circumstances of the time of its interpretation; an idea that endows the historian with the power of intervention. Likewise, Godard's freeassociational and montage-based rhetoric, which reorganizes the canon through unexpected relations, uses his history of cinema as a means to advocate his own philosophy rather than to forge an empirical reconstitution of the past as hypothetical "as it was." Rather than simply bowing to a tradition to which he nevertheless is indebted (as suggested by his tributes to Italian neorealism and Hitchcock), Godard transforms this tradition - and the director's image and voice-over commentary give body to the agent of such transformation.

The arbitrariness of Godard's historical account emphasizes an element of personal expression, evident in the inclusion of his own 
self as object of study: In the lecture that opens Introduction à une véritable histoire du cinéma, Godard compares talking about the history of cinema with psychoanalysis, the object being himself and his work; not his personal past, but his (by then) 20 years of filmmaking (Godard 24). The Montreal lectures included a retrospective that bore a comparative structure - Godard's films were shown alongside films by different artists. The counterpart for the Godard film, selected by the director, was always a work that he considered relevant for his career. To look at moving images from the past, he claimed, would constitute a form of self-psychoanalysis, a means to understand his very decision to make films (22).

Godard's own works contain elements of self-historicization, examples of which are, among many others, the self-criticism and self-revisionism of Weekend (1967), whose closing titles ("End of Cinema") announce both the transition to collective practices (the first Ciné-tracts date from 1968) and the self-criticism of Tout Va Bien (1972), which questions the role of intellectuals in social struggles. The Canadian lectures - the director's first draft of Histoire(s) - were already tinged with self-contemplation, something the series renders explicit. While chapter $1 \mathrm{~B}$ warns against such a personal dimension, printing the screen with titles reading "history, not the one who tells it," in 2B Godard alerts the viewer about the subjective tone of his discourse: "But to me, at first, mine, my history" and "these stories that are now mine, how to tell them?" flash throughout the episode. 1A displays a close-up of Anna Karina in Band of Outsiders followed by the director's image by his shelf saying Farewell My Lovely - a type of juxtaposition that constitutes both a cinematic' and a personal tribute by means of intertextual play. Godard introduces an autobiographical element, but one in which his life blends with cinema (Karina used to be both his wife and muse). Histoire(s) constantly deploys film titles to articulate personal thoughts; here, Godard resorts to intertextuality to look back at his own past (both personal and professional) with melancholy.

Godard's authorial agency is also materialized through the orchestration of filmic and photographic images of the director with 
his speech, as Roland-François Lack notes in his analysis of the director's voice as self-inscribing element ${ }^{9}$. Impersonal in its robotic aspect, Godard's rhythmic, monotonic, often whispered voice-over requires an effort on the part of the spectator - instead of reaching the audience, Godard's vocal interventions have to be sorted out, discriminated among the many sounds (film dialogues, music) that accompany it. The eventual slowing down of the narration's speed and the exploration of post-production effects such as echoes and reverberations de-personify Godard's utterances. At other times Godard's voice assumes a corporeal quality. The emphasis on texture and gutturalness displayed, for example, in the first episodes of the series, with Godard repeating words such as "the rules of the game," renders the director's voice almost palpable. These words simultaneously inscribe him into the film by way of the first-person pronoun - in French, notes Lack, the phrase constitutes a pun, "La règle du jeu [game]" being heard as "la règle du je [I]" (322).

Godard's voice thus "colors the image with its inimitable grain," as Jacques Aumont had written in Amnésies (11). The corporeal quality of Godard's narration ultimately recalls the idea of "writing aloud," or "vocal writing," that Barthes explores in The Pleasure of the Text. Rather than expressive, argues Barthes, writing aloud

leaves expression to the pheno-text, to the regular code of communication; it belongs to the geno-text, to significance; it is carried not by dramatic inflections, subtle stresses, sympathetic accents, but by the grain of the voice, which is an erotic mixture of timbre and language ... Due allowance being made for the sounds of the language, writing aloud is not phonological but phonetic; its aim is not the clarity of the messages, the theater of emotions; what it searches for (in a perspective

9. Roland-François Lack, 'Sa Voix,' in Michael Temple, James S. Williams and Michael Witt (eds.), For Ever Godard. London, Black Dog Publishing, 2004, 312333. 
of bliss) are the pulsional incidents, the language lined with flesh, a text where we can hear the grain of the throat, the patina of consonants, the voluptuousness of vowels, a whole carnal stereophony: the articulation of the body, of the tongue, not that of meaning, of language (66-7).

Godard's complex manipulation of his own voice-over discourse gives body to the director's vocal qualities, fully exploring cinema's ability to "capture the sound of speech in close-up ... and make us hear in their materiality, their sensuality, the breath, the gutturals, the fleshiness of the lips" (Pleasure 67). The author is thus materialized in the filmic text - as Barthes would put it, he figures in it. Barthes's idea of figuration (which is distinct from representation) defines the moments in which the text evokes the author, who appears "not in the guise of direct biography (which would exceed the body, give a meaning to life, forge a destiny)" (Pleasure 56). It follows that Godard's intertextual appropriations do not constitute foreign, alien elements. On the contrary, he blends these exterior objects into the textual (and vocal) "tissue" in which "the subject unmakes himself" (Pleasure 64).

In the end, Histoire(s) gives full body to the expressive filmmaker conceived by Astruc and embraced by the politique. Godard's practices rescue the multi-faceted director aligned with a French tradition of blending writing criticism and theory with filmmaking. To be sure, Godard never ceased to perform film criticism - if he has often claimed that reviewing films was a way of making films, ${ }^{10}$ his works had always been a way of "reviewing" other works through both citation and revisionism. In short, Godard's films have frequently amounted to a subjective and reflective historicization of cinema. The director's obsession with reinventing the medium incessantly evokes the past. The film program of the Montreal lectures, for example, indicates that he finds affinities between Breathless and Fallen Angel (1945) (Godard 25), and both the generic elements of his films from the 1960's and the self-referencing elements

10. MacCabe refers to Godard's conflation of film criticism and filmmaking (42) 
found throughout his career betray a constant concern with past and future - of cinema as a whole and of his own individual career.

Memory is ultimately pivotal in Godard's self-inscription; it constitutes a tool for the director's citation-based self-expression, one which incessantly evokes previous texts and images - thus the New Wave filmmaker as historian - while refusing to fix them in an indisputable past. What is more, the very ephemeral quality acquired by the brief and oftentimes abstract articulation of one image with the next, or of images and sounds, corroborates Godard's refusal to fix these cinematic reminiscences into any stable configuration. The absence of linearity prevents, for example, the memorization of specific juxtapositions, when it not simply separates, in the viewer's recollections, sounds from images. Finally, the series' erratic quality (the difficulty to locate a place of shooting and a place for projection) and its open-endedness on the levels of both meaning and structure add to Histoire(s) yet another element of instability.

While fleshing out an authorial voice, imprinting audio and visual tracks with his presence, Godard also "dissolves" into his images - to the point that he becomes the images themselves, as Scemama has argued $(10,25)$. Rather than confining such images to the palpable domains of his body, Godard expands the limits of his body, explodes it, opens it up to the multiplicity and infinitude of his Histoire(s), whose innumerable relations he inhabits. Speaking of Hitchcock in episode $4 \mathrm{~A}$, the director conflates style and man. The plural of the series' title multiplies the man - presenting him as Godard(s), and finally rhyming author and oeuvre on both an audible and a visual level.

\section{The author between camera and reality}

While relativizing what he admits to be his version of the history of cinema, Godard nevertheless fabricates a repertoire which, again, draws on a pre-existing canon. Concurrently, he articulates an historical account open to public access (the series was aired on French television). The tension between the individual and the collective that lies in the film's evoking of a subjective history, one that is nonetheless manufactured from elements of a collective 
archive, finds echo in Coutinho's documentary. Regardless of the extent to which Histoire $(s)$ is useful or accessible as historical source, its very designation as History automatically integrates the film into an archive. Yet this archive that both feeds and is fed by Histoire(s) inventorial practices, though shared by a cultural community made of spectators, artists and intellectuals, is certainly not the patrimony of a specific nation - even if, as stated above, Godard's historical discourse finds its genesis in his practices as a French New Wave director. Coutinho's documentary, conversely, reflects on the political trajectory of Brazil, albeit by means of the parallel between the lives of peasants and the life of an aborted film. Its national dimension takes the form of allegory, which in fact aligns Coutinho with a Brazilian tradition. Whereas Cinema Novo's translation of precariousness into style allegorized underdevelopment, ${ }^{11}$ Cabra allegorizes Brazil's transition from military rule to redemocratization by means of the trajectory of a censored film project brought back to life.

The tension between the individual and the collective found in Godard's appropriation of a cultural patrimony to articulate a subjective discourse goes beyond intertextual practices in Cabra, as in Coutinho's documentary the issue of nation takes the front seat. Both Ismail Xavier and Robert Stam have argued that Coutinho's incorporation of footage from his 1960's film in the final product displays a difference in style that is revelatory of the political transformations endured by the country throughout the 20 years that separate the original feature from the accomplished documentary. ${ }^{12}$. Coutinho's initial project was sponsored by both the Movement for Popular Culture of Pernambuco and the Center of Popular Culture, a branch of the Brazilian student movement that encouraged political militancy and didacticism. As Stam, Xavier and João Luiz Vieira point out in "The Shape of Brazilian Cinema in the Post-Modern Age," the

11. See Xavier, Ismail. Allegories of Underdevelopment. Minneapolis: University of Minnesota Press, 1997.

12. Stam, Robert, and Ismail Xavier. 'Transformation of National Allegory: Brazilian Cinema from Dictatorship to Redemocratization, in Michael T. Martin (ed.), New latin American Cinema, vol. 2. Detroit, Michigan: Wayne University Press, 1997. 318. 
black-and-white material shot in the 1960's reveals a didactic tone that echoed that period's belief in the masses as motor for revolution, displaying idealizing low angles and a realist aesthetics reminiscent of both American social dramas and Italian Neorealism (444). In La Terrat trema (1948) Luchino Visconti used improvisation to write the dialogues among the fishermen; likewise, Coutinho relied on the lines improvised by the peasants to dramatize their interchanges with a landowner's spokesperson. The colored images from the 1980's documentary, on the other hand, reveal a more dialogical and selfreflexive approach, with Coutinho onscreen interviewing his subjects, images of the crew and the film equipment, and the retaining of awkward moments where interviewees either refuse to talk or confront the filmmaker - all of which demystify the documentary as the only possible truth by revealing the meanders of its confection, thus asserting the film as manufacture, as artifice. Stam, Xavier and Vieira argue that, though calling to mind the 60's in its likeness to cinéma vérité, this dialogical and self-reflexive mode mirrors also the country's redemocratization and the consequent openness to dialogue, in addition to reflecting Coutinho's experience as a reporter for TV documentaries, an activity he undertook after temporarily withdrawing from filmmaking in the 1970's (444). The stylized staging of the 60's thus contrasts with the spontaneity conveyed in the informal, TV-like impromptu-ness found in the images from the 80 's. The cinematic marker of pastness par excellence, the black-and-white photography adds artificiality to the 1960's images. Though color, or lack thereof, is one more element setting apart the footages of the 60's and the 80 's, legitimizing the former as document, it also tints the past with artificiality at a moment in which colored television was setting the standards to realism, especially in a TV-dominated country like Brazil.

The informality detected in the footage from the 1980's contrasts also with what Jean-Claude Bernardet calls "the sociological model" observed in the Brazilian documentaries from the mid-60's opposing the people's life experiences to the documentarist's intellectual distanciation and capacity to generate theories. In this type of documentary, the interviewed subjects are limited to report their private experiences, while the documentarist ascribes to himself 
the elaboration of theoretical conclusions. Concisely put, the sociological model polarizes the dialogue between interviewee and interviewer, opposing the "voice of experience" to the "voice of knowledge" (Bernardet 16-7). Cabra avoids this polarization; not only does it give the interviewees the chance to confabulate on a political state of affairs, but the director also becomes the subject of his own film, incarnating himself the "voice of experience" - even if the domain of Coutinho's self-inscription is limited to the domain of his projects, as he exists only as the director of the two films in question.

The metalinguistic dimension of Cabra leads the director to speak in the first person - both in the singular and in the plural, when through the use of the pronoun "we" he includes the film's crew in his authorial project. It is clear that the voice-over narrations of Coutinho, Ferreira Gullar and Tite de Lemos do perform the bridging among characters; they do provide background information about the documentary's subjects, producing a discourse about them, even if not quite in the didactic form typical of the sociological model. Nonetheless, the very open-ended quality of the documentary unburdens the voice-over commentary, however explanatory, from the authoritative, God-like narrations of more traditional forms. It is also true that Coutinho sometimes corrects the documentary subjects about some of the facts of their own past, which he, as an investigator, had been excavating with the help of a large number of people involved, therefore having access to privileged information. As he locates those among Elisabeth's children who had been dispersed afterthe political persecution that followed the death of João Pedro, Coutinho displays a more accurate historical perspective over the life of the family than the children themselves. Elisabeth's offspring had no choice but to rely on the memories of the relatives who raised them, or else on their own childhood memories, most of them lost, since they had been separated from the family at a very early age. The director corrects a son who claims that João Pedro died in 1964, saying he was in fact assassinated in 1962; and tells a daughter that she was 8 months old when her father died, and not 3 , as she believes. However, Coutinho frequently leaves to the other voice-over commentators the task of narrating the characters' past, preferring to utter the more 
personal lines. The self-reflexive choice of placing his film (and often himself) as the documentary's subject leads him to transition back and forth from the "voice of knowledge" to the "voice of experience." Coutinho's narration is often self-narration - when the subject of his discourse is his abandoned project, what he reports is his experience (however dissolved by the use of the first plural), in addition to the experiences of others ${ }^{13}$.

Conversely, the subjects of Cabra often incarnate the "voice of knowledge." After living in clandestinity and under a different identity for 17 years, the leader's widow, Elisabeth, is caught by surprise in her new house by Coutinho's crew; and improvises a discourse about the practices of João Baptista Figueiredo (1979-1985) in which she thanks the last of the military presidents for launching the relaxation of censorship, allowing for an openness to dialogue which had been absent from public life since the military coup. Such a political discourse, as well as Elisabeth's assertion, in her final speech, that "the struggle goes on," adds to the film's curiosity about her individual experiences an interest in her worldview, in her capacity to express opinions on a political state of affairs - usually an attribute of the sociological model's "voice of knowledge." The same can be asserted about the political speech proffered by Abraão, Elisabeth's oldest son, a moment in which the subject of the documentary not only articulates a discourse about politics, however confusedly, but also addresses the film, demanding from the director that his family's repudiation of "any form of government" be registered, to which Coutinho immediately replies "It will be registered, I guarantee."

13. With Santo Forte (1999) Coutinho abandons any residue of the "voice of knowledge" by simply refusing to comment on the statements of his subjects. Structured as a talking-head documentary consisting of multiple characters reporting mystical and religious experiences, Santo Forte avoids voice-over introduction, bridging or commentary. Coutinho's voice is heard only as he interrogates his subjects-his "knowledge," in this case, lies in his appropriate silence, in his refusal to interpret or analyze the deeply intimate experiences informing a documentary topic (religion) that could only include analysis at the risk of incurring into judgment of values. A similar dynamics is found in Edificio Master. Both are discussed in Chapter 2. 
The very act of remembering provides these subjects with the temporal distanciation that allows for reflection. The choice to register the characters watching the old footage calls for the same kind of subject's self-reflexivity detected, for example, in Jean Rouch's and Edgard Morin's Chronicles of a Summer (1961), in addition to echoing Benjamin's calls for the workers' right over their images, as Roberto Schwarz notes in his essay on the film (74): It is true that by looking at subjects looking at themselves the film inevitably retains the final word; nevertheless, it gives voice to the characters' own impressions about the images from the past. The temporal gap, filled with the accumulation of other experiences, allows for a certain amount of self-reflexivity on the part of the film's subjects, in the form of a contemplation of their own past, which they contrast with their present - the viewing of the old images serves as a catalyst whose effect will be reflected in individual interviews. Schwarz claims that the 20 year period brings artistic force to the film, and material for reflection (71). The same holds true for Elisabeth's self-examining comment on her "performance" during Coutinho's first visit to her house, after tracking her down, offering her the opportunity to reveal her real identity, and breaking years of silence. The arrival of the crew and her willingness to go public surprise the neighbors who gather around her, unaware of her true identity. "I was very moved," she says to the director, on-camera, adding that she could have started the narrative of her experiences from the beginning, as Coutinho would have wished - words that nonetheless follow, in order, Coutinho's own interpretation of Elisabeth's change of behavior throughout the three encounters that take place in the 1980's - his belief, articulated in voice-over, that the overbearing presence of Abraão in the first meeting had intimidated her.

Finally, in Cabra the "voice of knowledge" is often the attribute of the interviewed peasants, who reveal facts about the interrupted project that are still unknown to the director himself. Part of the documentary is dedicated to the investigation of the destiny of the film cans and equipment after Coutinho and his crew flee Galiléia in 1964 to avoid prison. As the director interrogates José Virgilio and his son, who had been in charge of the equipment during the 1960's 
shoot, he learns facts about the life of his own film. The two men show to Coutinho the place where they hid the camera from the army; in addition, they reveal that the government and the police believed the crew was made of infiltrated Cuban revolutionaries, and that João Virgílio's son refused to turn in a book that belonged to one of the crewmembers - Curzio Malaparte's Kaputt. The young man reads the book's preface out loud, opening the way for Coutinho to establish a relationship between book and film: as Bernardet points out, Kaputt too had its fragments hidden by several of the writer's friends, in particular a Polish peasant, in order to avoid destruction in the hands of a repressive government (229) - namely, the Gestapo. Meanwhile, Schwarz notes a parallel between Coutinho and Elisabeth - Cabra constitutes the director's return to both the cinema and a political project abandoned after the military coup, just as it offers to Elisabeth the opportunity to both reveal her true identity and resuscitate her political activism through the memory of her. struggles (72). Elisabeth's life thus mirrors Coutinho's own intellectual and political trajectory.

The contrast between private experience and political theory in Coutinho's revision of the "sociological model" constitutes only one dimension of the opposition between the individual and the collective in Cabra. The other lies in the narration of the country's transition from dictatorship to democracy through the life-stories of the characters involved in the peasant struggle. The experiences of Elisabeth stand in for the experiences of many Brazilians whose lives were disrupted by the dictatorship: the loss of loved ones, the dissolution of the family, the persecution paranoia, the prison, the exile, the clandestine life. The parallel between individual and national narratives, articulated in the form of allegories in which individual stories acquire a symbolic dimension, dialogue with a Brazilian tradition - from the allegorization of anthropophagy in the cannibalization of a French explorer in Nelson Pereira dos Santos's How Tasty Was My Little Frenchman (1971) to the parallel between self-discovery and the exploration of sertão in Walter Salles's Central Station (1998). Likewise, Coutinho's accomplishments stand in for the accomplishments of Brazilian cinema as a whole 
(Stam, Xavier 297), a phenomenon not uncommon in a country where the hardships of funding and producing a film unite directors under the struggle against a cultural state of affairs, the finishing of each film turning into a victory for national cinema itself. Though it is clear that Cabra is a personal project, and even if Coutinho is the only identifiable figure to appear on screen, the filmmaker speaks in the plural, suggesting the constant presence of his crew - yet another element that posits in the director's figure the activities and discourses of many.

The orchestration of the testimonies of "the people" evokes also the Brazilian model of film authorship, in which directors desire to give voice to the nation so as to reveal and scrutinize it. Whereas in Histoire(s) the orchestration of the discourses of others consists in articulating intertextual appropriations, what Coutinho orchestrates in Cabra is the discourses of his interviewees, intercalated with a variety of styles ranging from cinéma vérité to Neorealism to television, the testimonies of written documents, such as the various images of newspaper clips, and different voice-over narrators. Additionally, just as Godard's approach to history de-stabilizes the past by placing canonical images in new relations, re-signifying them and breathing new life into them, Coutinho's approach reveals the past as unfixed object, as unconcluded narrative. Thus the openendedness suggested in the contradictory testimonies of Cabra, most of which are left unresolved. Mariano, the peasant who in the 60's played the role of João Pedro, speaks of religious conversion and the consequent renunciation of the revolutionary cause, at once siding with the church, thus condemning the revolution, and resenting the fact that this very church forbids him to partake in the peasant struggle. Furthermore, the delivering of information by other narrators, along with the multivoiced quality of a documentary constituted by multiple interviews, also opens the way to multilateral interpretations of the past, expressed in the many perspectives offered by those memories produced many years later.

While Godard articulates his historical discourse from his editing room, in isolation, Coutinho travels to the depths of Brazil to collect testimonies, working collectively, in physical contact with the 
producers of the discourses that inform his documentary ${ }^{14}$. Relying largely on montage and sound effects, Godard's self-inscription in Histoire(s) is configured mainly in post-production, in the editing room; Coutinho's presence, in turn, is felt at the level of the profilmic, on location. In tune with Cinema Novo's desire to reveal the nation, Coutinho constructs a discourse that is composed of the voices of the "people;" his authorial input lies in the ways in which his presence shapes their testimonies. It is via the thematization of Coutinho's intervention in the events filmed that Cabra provides a discussion of authorship that contrasts with the films by Godard; in the thematization of the impact of the director's physical presence in the testimonies of his interviewees ${ }^{15}$, both as an agent instigating their remembrance of things past and as a figure that renders the subjects self-conscious, sometimes performative, sometimes intimidated.

In reality, the liveliness of the testimonies provided by the characters in the 80 's, often adorned by certain theatricality in their reproduction, for example, of dialogues with the police, favor the very act of remembering. Coutinho's physical presence functions as a reminder of the effects of the cinematic apparatus on people's speeches; Cabra indeed privileges the truth of the moment of their testimonies, rather than an unchangeable truth shared by all. More powerful than Mariano's abandonment of the peasant struggle in the name of religion is his hesitation to speak about his militant past to the camera, increased by a sound problem that requires that Coutinho interrupt his interviewee for a few seconds. In this sequence, Coutinho nearly loses Mariano, who, visibly upset, pauses for a long time before finally deciding to go ahead with his speech. The very issue of truth is relativized when the sincerity of the characters' words becomes questionable, as when, in tears,

14. I would like to acknowledge Xavier's insights about this issue

15. Xavier has articulated the impact of Coutinho's presence as "the camera-effect." See Ismail Xavier, "Indagações em torno de Eduardo Coutinho e seu diálogo com a tradição moderna" [Questions about Eduardo Coutinho and his dialogue with the modern tradition], in Eduardo Coutinho: Cinema do Encontro. Catalog for the series "Mostra Diretores Brasileiros," organized by Centro Cultural Banco do Brasil in 2003.Authorship in the Interstices of History, Biography, Reality and Memory: Histoire(s) du Cinema and Cabra Marcado para Morrer.

Significação $26 \bullet 166$ 
Elisabeth's daughter claims not to resent her mother for giving her away when she was a few months old, even if she never understood why: The truth here, like in Mariano's.testimony, lies in the contrast between the young woman's evident grief and her words; rather than in the content of her speech.

Cabra essays also the impact of exterior circumstances on the film. Chief among them, of course, is the very interruption of its initial version by governmental censorship, as well as the apprehension and destruction of part of the original footage. Had the initial film been completed; the documentary we see would have probably never come to be. The voice-over narrators tell us also that the initial idea was to have João Pedro's real colleagues and children reenact the events of his life. Due to an armed conflict between peasants and local authorities, Joã̀o Pedro's hometown, Sapé, hâd been closed for the shoot, 'obliging Coutinho to relocate the crew to a different town,'Galiléia, and hire local peasants, also militant, to work in the film - retaining only Elisabeth.

The "understanding that cinema captures not an exterior reality'; but the reality of the encounter between filmed object and camerä, echoes Godard's theoretical writings' from the 1950's: as MacCabe reminds us, "For Gódard, there is not reality and then the camera - there is reality seized at this moment and in this way by the camera" (79). The greatest affinity between Godard and Coutinho lies in their dialogue with cinéma-verite - in other words, in their awareness of the impact of the camera on a filmed reality. Thus the acting style that prevails in Godard's films being one in which rather than ignoring the camera in order to fully immerse themselves in the fictional world and incarnate their characters, actors are aware of the camera, indeed address it, and emphasize representation over realism, resulting in schematic and stereotyped actions. Instead of simply depicting a fictional world, Godard films constitute, as he used to say, documentaries about the actors. Works like Pierrot le Fou, Masculine Feminine and Two or Three Things I Know About Her even display documentary-like moments in which actors and non-actors talk about themselves to the camera. 
Coutinho's intervention in the reality he films is felt yet in even deeper, more significant ways. In addition to bringing back to light the true identity of Elisabeth, the director attempts to promote the reunion between mother and children, which would constitute an exceptional, yearned-for case in which cinema interferes with life, rendering palpable the effects of an authorial agency already substantiated in the director's onscreen presence. The promotion of social change advocated in the Brazilian and New Latin American cinemas' dream of instigating audiences to the point of leading them to political action is here circumscribed to the profilmic. In fact, Coutinho's film registers, as much as provokes, the social transformations that marked the transition to redemocratization. By providing Elisabeth with freedom of speech, Coutinho functions as an agent for the relaxation of political repression that allows him to disclose her story - he even guarantees the safety of his subjects, as when interviewing a suspicious Mariano he promises that the peasant can speak openly and with no fear. Bernardet points out, nevertheless, that the transformations brought about by Coutinho in the reality he films have the duration of the film itself (234). The ex-companions in political struggle gathered to watch the screening promoted by Coutinho showing footage of the 1960's soon disperse again once the shooting of the documentary is over (Bernardet 234). At the closing of Cabra, we are told that Elisabeth had thus far met only two out of the eight children she had lost track of, while Coutinho himself had managed to find six of them. Bernardet suggests that the fragments dispersed by reality can be assembled only within the domains of the spectacle (234-5); according to this view, Coutinho's physical impact on the reality filmed dies with the end credits.

However, rather than limit the impact of the film to the moment of its confection, these transformations simply do not completely fulfill the documentarist's expectations - yet they certainly reverberate in the subjects whose lives were changed by the documentary. No study has attempted to constantly follow up on the state of the family many years after the film's release. For the viewer, the documentary's greatest impact is necessarily the one registered by the camera. The author's agency is measurable 
within the confines of the text; as is whatever transformation his film brings to the lives of his subjects. If Histoire( $s)$ echoes the method of the between, privileging the collision between images or historical events, Coutinho privileges the collision between documentarist and human subject over an objective reality existing beyond this encounter. Evoking the embodiment of national cinema by heroic individuals undertaking several tasks, Cabra contemplates the relation between cinema and life through the impact of the filmmaker on his interviewees.

The reality that is valid only within the domains of the film is also determinant in documentaries such as Santo Forte (1999), Babilônia 2000 (1999), Edifício Master (2002), Peões (2004), and $O$ Fim $e$ o Princípio (2005). In "Sentido e Verdade" [Sense and Truth], José Padilha describes a discussion between Coutinho and Albert Maysles organized by the Pontificia Universidade Católica (PUC) in Rio de Janeiro. During the event, Coutinho claimed not to be interested in the truth of the testimonies collected in Edificio Master, but in the encounter between documentarist and subject apparently raising protests on the part of Maysles. As Padilha points out, Coutinho's statement reveals a filmmaker documenting not objective events, but the subjective ways in which people deal with specific circumstances (65). Santo Forte reveals mystical and religious experiences, while Babilonia and Edifício Master focus on how people cope with their environment - the favela in the first, a decadent Copacabana building in the second (Padilha 64-5). In sum, these films are concerned with the interviewees' subjectivity at the moment of the interview, rather than with an objective reality existing beyond the domains of the film (Padilha 65). Following a screening of $O$ Fim e o Princípio during the XIII Visible Evidence, Coutinho suggested to the audience that memory belongs to the present. The director speculated that, if asked to talk about their childhood at different moments, a subject would never describe the same event twice. The present thus determines the memory of the past, and Coutinho's later works perpetuate the emphasis placed on the moment in which filmmaker and subject encounter-emphasis whose genesis is found in Cabra. 
The privileging of the encounter over accuracy, of the director's impact on his interviewees over a pre-existing reality, places Cabra alongside Histoire( $s$ ) in the centrality of memory to the construction of historical discourses. Both Histoire (s) and Cabra reconstruct historical events through the assembling of several discourses in non-linear narratives. Both privilege a Benjaminian understanding of history as mutable and unstable, as open process rather than closed narrative. Finally, the materializing of film's discursive mode in the figure of directors asserts the image as document, as record of the author's agency, while at the same time de-stabilizing its documental legitimacy through montage and emphasis on artifice. The dialogical approach to the cinematic image on the part of both Godard and Coutinho is mirrored in their configuring the past as construction and present praxis rather than permanent, stoic reference.

\section{Bibliography}

AUMONT, J. 1999. Amnésies. Paris: P.O.L.

BAKHTIN, M. M. 1974. Problems of Dostoevsky's Poetics, trans. Caryl Emerson. Minneapolis: University of Minnesota Press, 1984, and Metz, Christian. Film Language, trans. Michael Taylor .New York: Oxford Univ. Press.

BARTHES, R. "The Death of the Author." 1968. Theories of Authorship: a Reader. Ed. John Caughie. London; Boston: Routledge \& Kegan Paul in association with the British Film Institute, 1981. 208-213.

1975. The Pleasure of the Text, trans. Richard Miller. New York: Hill and Wang.

BENJAMIN, W. 1976. "Theses on the Philosophy of History." Illuminations. Ed. Hannah Harendt. New York: Shocken Books, 253-267.

1999. The Arcades Project, transl. Howard Eiland and Kevin McLaughlin. Cambridge, Mass.: Belknap Press.

BERNARDET, J-C. 2003. "O modelo sociológico ou a voz do dono: Viramundo" and "Vitória sobre a Lata de Lixo da História: Cabra 
Marcado para Morrer." Cineastas e Imagens do Povo. São Paulo: Companhia das Letras, 15-39, 227-42.

DALL'ASTA, M. "The (Im)Possible History." For Ever Godard. Ed. Michael Temple, James S. Williams and Michael Witt. London: Black Dog Publishing, 2004. 350-363.

GAUDREAULT, A. 1999. Du Littéraire au Filmique. Quebec: Editions Nota Bene.

GENETTE, G. 1980. Narrative Discourse. Ithaca: Cornell UP.

GODARD, J-L. 1980. Introduction à une véritable histoire du cinema - Tome I. Paris: Editions Albatrox.

GRUNER, E. 2003. "JLG, o el absoluto de la accion." Jean-Luc Godard: El Pensamiento del cine: Cuatro miradas sobre Histoire(s) du Cinéma. Ed. David Oubiña. Buenos Aires, Barcelona \& Mexico: Paidos, 79-104.

GUNNING, T. 1991. D.W. Griffith and the Origins of American Narrative Film: the Early Years at Biograph. Urbana: University of Illinois Press.

. 2000. The Films of Fritz Lang: Allegories of Vision and Modernity. London: BFI Publishing.

HORI, J. "Godard's Two Historiographies." For Ever Godard. Op. Cit. 334-349.

LACK, R-F. "Sa Voix." Michael Temple, James S. Williams and Michael Witt (eds.), For Ever Godard. Op. Cit. 312-333.

MACCABE, C. 2004. Godard: Portrait of the Artist at Seventy. New York: Farrar, Straus and Giroux.

METZ, C. 1974. Film Language: A Semiotics of the Cinema. Trans. Michael Taylor. New York: Oxford Univ. Press.

MORREY, D. 2005. Jean-Luc Godard. Manchester and New York: Manchester University Press.

PADILHA, J. 2003. "Sentido e Verdade." Cinemais 36 (Oct. Dec.), p. 59-70.

SCEMAMA, C. 2006. Histoire(s) du cinéma de Jean-Luc Godard: la force faible d'un art. Paris: Harmattan.

SCHWARZ, R. 1987. "O Fio da Memória" (1985). Que Horas São? Ensaios. São Paulo: Companhia das Letras. 
STAM, R. and XAVIER, I. 1997. "Transformation of National Allegory: Brazilian Cinema from Dictatorship to Redemocratization." New Latin American Cinema, vol. 2. Ed. Michael T. Martin. Detroit, Michigan: Waye University Press, 295-322.

1995. João Luiz Vieira and Ismail Xavier. "The Shape of Brazilian Cinema in the Postmodern Age." Brazilian Cinema. Ed. Robert Stam and Randal Johnson. New York: Columbia UP, 387-472.

XAVIER, Ismail. 1997. Allegories of Underdevelopment: Aesthetics and Politics in Modern Brazilian Cinema. Minneapolis: University of Minnesota Press.

.2003. "Indagações em torno de Eduardo Coutinho e seu diálogo com a tradição moderna." Eduardo Coutinho: Cinema do Encontro. Catalog for the series "Mostra Diretores Brasileiros," organized by Centro Cultural Banco do Brasil in 51-9. 